\title{
AN EMPIRICAL ANALYSIS OF THE DIFFUSION OF INFORMATION ACROSS STOCK MARKETS OF CENTRAL AND EASTERN EUROPE
}

\section{Ovidiu Stoica, Mark J. Perry, Seyed Mehdian*}

\begin{abstract}
:
In this paper, we examine the efficiency of the transmission of information across the stock markets of Bulgaria, the Czech Republic, Hungary, Poland, Romania, and Slovakia, as well as the relative importance and influence of advanced equity markets of Germany and France on the abovementioned markets. The analysis is carried out using maximum likelihood regressions, Generalized Autoregressive Conditional Heteroskedastic (GARCH) models, and vector autoregression (VAR) estimations.

The empirical results suggest that the Central and Eastern European stock markets react to the arrival of price innovations from Germany and France, but national stock market price innovations account for more error variance compared to those of Germany and France, and generally show an increasing responsiveness over time, which could be interpreted as progress in the European financial integration.
\end{abstract}

Keywords: diffusion of information, integration of equity markets, Central and Eastern European countries, European integration.

JEL Classification: G14, G15

\section{Introduction}

The integration of financial markets in Central and Eastern Europe (CEE) emerged subsequent to the collapse of the Soviet Union, the reunification of Germany, and the adoption and growth of the market economy. This financial integration intensified following the creation and expansion of the European Union (EU), when it offered membership to CEE countries. The stock markets of Eastern and Western Europe have increasingly become more inter-connected, as CEE financial markets continued to develop, and daily trading volume and total market capitalization to grow significantly. This process of financial integration in European countries has taken place concurrently with the overall globalization of financial markets in general, and equity markets in particular.

Stronger integration of financial markets in the presence of internationalization may reduce the power and advantage of diversification; nonetheless, the dissemination of

* Ovidiu Stoica, Professor of Finance, Faculty of Economics and Business Administration, “Alexandru Ioan Cuza” University of Iasi, Iasi, Romania, (ostoica@uaic.ro);

Mark J. Perry, Professor of Finance and Business Economics, School of Management, The University of Michigan-Flint, Flint, USA, Resident Scholar, the American Enterprise Institute,(mjperry@umich.edu);

Seyed Mehdian, Professor of Finance, The University of Michigan-Flint, Flint, USA, (seyed@umich.edu). 
information across financial markets is vital for portfolio managers to construct optimal portfolios. It is further apparent that stock markets have become increasingly important as a source of raising funds for public companies in CEE countries.

A large number of existing studies have investigated the correlations and interdependencies among stock returns, the transmission of information, leakages, and price innovations across international equity markets in order to implement adequate diversification strategies (see for example Bailey and Stulz, 1990; Koch and Koch, 1991; Cheung and Ho, 1991; Ng, 2000; Dickinson, 2000; Longin and Solnik, 2001; Forbes and Rigobon, 2002; Shachmurove, 2005; Wongswan, 2006; Baltzer et al., 2008; Bora et al., 2009; Yalama, 2009; Dimpfl and Jung, 2011; and Peša and Festić, 2012). Harrison and Moore (2009) and Yalama (2009), for instance employed several econometric models to investigate the spillover effects and co-movements between the stock markets of the U.K. and Germany and selected CEE equity markets without emphases on continental Europe. They found spillover effects, and observed that Western equity markets influence CEE markets to different degrees. In addition, these authors provided evidence that volatility transmissions within a market are greater than inter-market volatility transmissions. Similarly, Ajayi, Mehdian and Perry (2010) examined the relative influences of markets in the U.S., the U.K. and Japan on Bahrain, Egypt, Israel, Jordan, Kuwait, Oman and Saudi Arabia. They found that the reaction of Middle Eastern countries to price innovations transmitted from the U.S., U.K. and Japan depends on the level of market development of these countries. The responses of Middle Eastern equity markets to price volatilities from the U.S. and the U.K., however, seem to be stronger than those from Japan.

While the relationship among emerging and advanced financial markets has been investigated extensively, there are few published studies that focus on the degree of integration of the new European Union countries of Central and Eastern Europe, on a preand post-accession basis. Our paper is motivated by this gap in the literature. Specifically, we examine the transmission of information across the stock markets of Bulgaria and Romania ${ }^{1}$ and the Czech Republic, Hungary, Poland, and Slovakia ${ }^{2}$ to assess empirically the degree of integration of these Central and Eastern Europe equity markets. We, furthermore, investigate the relative impact of the advanced equity markets of continental Europe (i.e. Germany and France) on these CEE equity markets, with regard to the transmission of price innovations. We decided to focus on continental Europe and chose not to include the U.K. in the study because of the stronger bond between the CEE countries and Germany and France. Germany and France belong to the euro area, and have substantial financial/political involvement in the CEE region with well-built social/ historical connections. Since among the new member states, our focal point is on the CEE countries out of the euro area, we have eliminated Slovenia from our sample.

To explore the nature of the transmission of financial information, the effect of external price innovations across the CEE equity markets, and the interdependency of the national stock markets during pre- and post-accession to the EU, we employ three econometric models: namely, maximum likelihood regression, GARCH, and vector autoregression (VAR).

The findings of this study facilitate an enhanced insight on the subject of the integration and interactions of CEE equity markets and provide individual investors and portfolio

$1 \quad$ Joined the European Union in January 2007.

2 Joined the European Union in May 2004. 
managers with valuable information regarding asset pricing, as well as the characteristics of spillover effects in these markets.

The empirical results of our study generally suggest that, while the CEE equity markets are influenced by their own price innovations and internal shocks, we observe some reaction from the CEE stock markets to the arrival of price innovations from Germany and France. Nevertheless, the pattern and nature of these reactions and responses are mixed across the markets under study. In addition, we observe that the national market price innovations account for more of the error variance for daily returns than the price innovations from the stock markets of Germany or France.

The rest of the paper proceeds as follows: Section 2 briefly describes the development of CEE equity markets during pre- and post-accession to the EU. Section 3 explains the data and the methodologies used. Section 4 discusses the empirical results, while Section 5 offers conclusions.

\section{A Brief Review of Central and Eastern European Stock Markets}

In the last twenty years, European stock markets have experienced impressive changes due to various alliances, acquisitions and mergers. Especially, during the last ten years, the landscape of the European stock markets was transformed because of the demutualization of stock exchanges, mergers and acquisitions, consolidation and fragmentation (Erkan, 2008). At the same time, the majority of not-for-profit stock exchanges converted to for-profit status, and large stock exchange groups emerged in Europe. The creation of Euronext in 2000, the first merger between three stock markets from three different countries, namely Amsterdam, Brussels and Paris Stock Exchange, fueled an intense ambition for cross-border mergers and acquisitions among the stock exchanges worldwide. OMX, after several acquisitions, mergers and alliances, succeeded to concentrate seven Nordic and Baltic stock markets. When NASDAQ agreed to buy the OMX Group on May 25, 2007, the NYSE Group had already merged with Euronext to form the first global exchange, signalling the beginning of a new era of stock exchange groups' involvement in operations across two continents. Similarly, the intention of merger between Deutsche Börse AG and NYSE Euronext Inc. and the London Stock Exchange with Canada's TMX Group, demonstrated the increasing competition among stock exchanges, and the strive for the first positions in the global hierarchy of market capitalizations.

In addition to considerable merger and acquisition activity at the top of world market capitalizations, there has also been activity at middle-range market capitalizations for alliances, mergers and/or acquisitions. Beyond those mentioned above, several other stock exchanges have expanded their control abroad and across Europe. For instance, during recent years, the Warsaw, Vienna and Athens Stock Exchanges have been the major players in the CEE area, showing a tremendous amount of enthusiasm for partnerships or acquisitions to expand their regional influence.

Since 2004, the Vienna Stock Exchange (VSE) continuously monitored the CEE area with the goal of expansion. Thus, in 2004 the VSE bought shares in the Budapest Stock Exchange, bought the majority of shares in Ljubljana Stock Exchange (competing with Hellenic Exchanges, Warsaw Stock Exchange, Bucharest Stock Exchange and OMX) in June 2008, and in November 2008 obtained control of the Prague Stock Exchange (in competition again with the Warsaw Stock Exchange). After including the three newly 
acquired CEE stock exchanges (Budapest, Ljubljana, and Prague), the Vienna Stock Exchange created the CEE Stock Exchange Group (CEESEG) in September 2009, which became the most important player in Central and Eastern Europe, with a market capitalization higher than the Warsaw Stock Exchange.

The Warsaw Stock Exchange is the main rival of CEESEG. It is expected to pursue growth strategies and expand regionally. The degree of its attraction was demonstrated by the interest shown in 2009 during the privatization process, when the Deutsche Börse, London Stock Exchange, NASDAQ-OMX and NYSE Euronext all submitted bids to purchase a stake in the Warsaw Stock Exchange.

Table 1 displays the market capitalization and the number of listed companies in selected European stock markets for 2000, 2005, 2010 and 2011. As shown, the Polish Stock Exchange has enjoyed the highest market capitalization in the CEE area during the last decade. Using Vienna for comparison, the Polish Stock Exchange has posted 51.14\% higher market capitalization compared to the Vienna Stock Exchange in 2011, with a significantly higher number of listed companies. Considering the financial dimensions of the two countries, the growth potential for the Polish market seems to be plausible. Prague, Budapest or Ljubljana stock markets alone remain among the smallest European markets, but the CEESEG aggregated capitalization, including Vienna, is the highest in the region.

After the creation of CEESEG, the potential for expansion in the CEE region became limited. Consequently, among the new EU members, only the Bucharest, Sofia and Bratislava stock exchanges stayed out of an alliance. To increase the regional influence, the stock exchanges interested in expansion turned their attention towards the emerging European markets outside the European Union. For instance, the Vienna Stock Exchange established cooperation arrangements with several small Balkan stock markets, including Sarajevo, Montenegro, Banja Luka, and Macedonia stock exchanges.

In July 2011, the Bucharest Stock Exchange (BSE) purchased 5\% of the shares from the Moldavian Stock Exchange, the only stock exchange in the Republic of Moldova. The BSE also showed an interest in participating in the privatization process of the Bulgarian stock exchange, which was transformed to a public company in December 2010. In April 2011, the CEO of the Bucharest Stock Exchange said that it had 5 million euros prepared to invest in the regional expansion. Similarly, in early November 2011, the Bucharest and Bulgarian Stock Exchanges signed a Memorandum of Understanding.

These transformations imply an environment of continuously changing landscapes, and strive for development. Moreover, the intense integration among the equity markets could lead to easier contagion/diffusion of information. With similar infrastructures, same intermediaries, and investors, the European financial setting favours an increasing responsiveness and a stronger reaction to price innovations from more mature markets. 
Table 1 | Market Capitalization (in millions of euros) and Number of Listed Companies in European Stock Markets in 2000, 2005, 2010 and 2011

\begin{tabular}{|c|c|c|c|c|c|c|c|c|}
\hline Stock Exchange & $\begin{array}{c}\text { Market } \\
\text { Cap. } 2011\end{array}$ & $\begin{array}{c}\text { Market } \\
\text { Cap. } 2010\end{array}$ & $\begin{array}{c}\text { Market } \\
\text { Cap. } 2005\end{array}$ & $\begin{array}{c}\text { Market } \\
\text { Cap. } 2000\end{array}$ & $\begin{array}{c}\text { No. of } \\
\text { Listed } \\
\text { Firms } \\
2011\end{array}$ & $\begin{array}{l}\text { No. of } \\
\text { Listed } \\
\text { Firms } \\
2010\end{array}$ & $\begin{array}{c}\text { No. of } \\
\text { Listed } \\
\text { Firms } \\
2005\end{array}$ & $\begin{array}{c}\text { No. of } \\
\text { Listed } \\
\text { Firms } \\
2000\end{array}$ \\
\hline NYSE Euronext & $2,254,590$ & $1,949,256$ & $1,849,978$ & $2,309,161$ & 1,133 & 1,155 & 997 & 1,288 \\
\hline $\begin{array}{l}\text { Germany } \\
\text { (Deutsche Börse) }\end{array}$ & $1,075,579$ & 863,011 & 858,366 & $1,442,696$ & 755 & 775 & 814 & 8,356 \\
\hline $\begin{array}{l}\text { Poland } \\
\text { (Warsaw Stock } \\
\text { Exchange) }\end{array}$ & 141,812 & 108,114 & 50,571 & 31,495 & 596 & 489 & 218 & 205 \\
\hline $\begin{array}{l}\text { Austria } \\
\text { (Vienna Stock } \\
\text { Exchange) }\end{array}$ & 93,829 & 78,709 & 66,479 & 31,833 & 108 & 115 & 119 & 113 \\
\hline $\begin{array}{l}\text { Czech Republic } \\
\text { (Prague Stock } \\
\text { Exchange) }\end{array}$ & 34,336 & 32,908 & 23,741 & n.a. & 27 & 26 & 55 & n.a. \\
\hline $\begin{array}{l}\text { Hungary } \\
\text { (Budapest Stock } \\
\text { Exchange) }\end{array}$ & 22,339 & 21,586 & 21,978 & 17,470 & 51 & 46 & 46 & 66 \\
\hline $\begin{array}{l}\text { Romania } \\
\text { (Bucharest Stock } \\
\text { Exchange) }\end{array}$ & 13,340 & 9,477 & 15,311 & 450 & 75 & 64 & 64 & 114 \\
\hline $\begin{array}{l}\text { Slovenia } \\
\text { (Ljubljana Stock } \\
\text { Exchange) }\end{array}$ & 6,747 & 8,505 & 7,347 & 3,152 & 71 & 76 & 141 & 132 \\
\hline $\begin{array}{l}\text { Bulgaria } \\
\text { (Bulgaria Stock } \\
\text { Exchange) }\end{array}$ & 5,803 & 5,886 & 3,980 & n.a. & 390 & 396 & 330 & n.a. \\
\hline $\begin{array}{l}\text { Slovakia } \\
\text { (Bratislava Stock } \\
\text { Exchange) }\end{array}$ & 3,404 & 3,547 & 3,212 & n.a. & 163 & 172 & 289 & n.a. \\
\hline
\end{tabular}

Source: http://www.fese.be/, http://www.bvb.ro

\section{Data and Methodology}

\subsection{Data}

We use daily closing values of stock market indexes from Germany and France to represent continental Europe, and Bulgaria, the Czech Republic, Hungary, Poland, Romania and Slovakia to represent the CEE markets. The sample covers a period from January 10, 2000 to September 30, 2010 for all indexes, except for Bulgaria, which starts on October 23, 2000. All of the daily stock market indexes were collected from Global Financial Data. We assume that stock price innovations capture all market related information.

We compute daily returns for each stock market using the daily closing values of each stock market index as follows:

$$
R_{i t}=\ln \left(\mathrm{I}_{i t} / \mathrm{I}_{i t-1}\right) * 100
$$


Where:

$R_{i t}=$ the daily return of stock market index $i$ on day $t$;

$\ln =$ natural $\log$;

$\mathrm{I}_{i t}=$ the closing value of stock market index $i$ on day $t$; and

$\mathrm{I}_{i t-1}=$ the closing value of stock market index $i$ on day $t-1$.

Then, we next performed Augmented Dickey-Fuller unit root tests on each series and were able to determine statistically that all daily stock returns meet the classical time series condition of being stationary in first difference.

Table 2 displays the descriptive statistics of the daily returns for each of the national stock market indexes. As shown, the Bucharest SE index has the highest mean daily return $(0.1033 \%)$ with the highest standard deviation of daily returns $(1.8429 \%)$, whereas the German DAX index had the lowest mean daily return $(0.0002 \%)$ with a standard deviation of $1.6505 \%$. In addition, we note that daily stock returns in the Bulgarian market experienced high volatility with a daily standard deviation of $1.8420 \%$, a daily maximum-minimum return range of $42.31 \%$, and a mean daily return of $0.0720 \%$.

Table 2 | Descriptive Statistics of Daily Returns for National Stock Market Indexes

\begin{tabular}{|l|c|c|c|c|c|c|}
\hline Country & $\begin{array}{c}\text { Stock } \\
\text { Index }\end{array}$ & $\begin{array}{c}\text { Sample } \\
\text { Period }\end{array}$ & Mean (\%) & $\begin{array}{c}\text { Std Dev. } \\
\text { (\%) }\end{array}$ & Min. (\%) & Max. (\%) \\
\hline Bulgaria & SE SOFIX & $\begin{array}{c}10 / 23 / 2000 \\
\text { to } 9 / 30 / 2010\end{array}$ & 0.0720 & 1.8420 & -18.8521 & 23.4583 \\
\hline $\begin{array}{l}\text { Czech } \\
\text { Republic }\end{array}$ & $\begin{array}{c}\text { Prague SE } \\
\text { PX }\end{array}$ & $\begin{array}{c}1 / 10 / 2000 \text { to } \\
9 / 30 / 2010\end{array}$ & 0.0430 & 1.5850 & -14.9435 & 13.1609 \\
\hline France & CAC-40 & $\begin{array}{c}1 / 10 / 2000 \text { to } \\
9 / 30 / 2010\end{array}$ & 0.0100 & 1.5777 & -9.0368 & 11.176 \\
\hline Germany & DAX & $\begin{array}{c}1 / 10 / 2000 \text { to } \\
9 / 30 / 2010\end{array}$ & 0.0002 & 1.6506 & -8.4860 & 11.4019 \\
\hline Hungary & $\begin{array}{c}\text { Budapest } \\
\text { Stock }\end{array}$ & $\begin{array}{c}1 / 10 / 2000 \text { to } \\
9 / 30 / 2010\end{array}$ & 0.0499 & 1.6839 & -11.8817 & 14.0854 \\
\hline Pxchange & $\begin{array}{c}\text { Poland } \\
\text { Warsaw SE } \\
\text { R-Share }\end{array}$ & $\begin{array}{c}1 / 10 / 2000 \text { to } \\
9 / 30 / 2010\end{array}$ & 0.0253 & 1.7024 & -8.0962 & 8.4966 \\
\hline Romania & $\begin{array}{c}\text { Bucharest } \\
\text { SE Index }\end{array}$ & $\begin{array}{c}1 / 10 / 2000 \text { to } \\
9 / 30 / 2010\end{array}$ & 0.1033 & 1.8429 & -12.2929 & 11.1427 \\
\hline Slovakia & $\begin{array}{c}\text { Bratislava } \\
\text { SE SAX } \\
\text { SE }\end{array}$ & $\begin{array}{c}1 / 10 / 2000 \text { to } \\
9 / 30 / 2010\end{array}$ & 0.0502 & 1.2771 & -13.7656 & 12.6148 \\
\hline
\end{tabular}


We also estimated correlation coefficients among stock returns of CEE countries, France, and Germany for the entire sample period and the results are presented in Table 2a. We note, as one would expect, that there is a strong correlation between daily returns for the two Romanian stock indexes (the BSE index and BSE composite index), and between the stock indexes of Germany and France (the DAX and CAC). One interesting finding, however, is the very low correlations between Slovakian stock returns and returns from the other stock indexes during the 10 -year period.

Table 2a | Correlation Matrix for National Stock Market Indexes, Full Sample Period (1/10/2000 to 9/30/2010)

\begin{tabular}{|l|l|l|l|l|l|l|l|l|}
\hline & Bulgaria & $\begin{array}{c}\text { Czech } \\
\text { Republic }\end{array}$ & France & Germany & Hungary & Poland & $\begin{array}{c}\text { Romania } \\
\text { (BSE) }\end{array}$ & $\begin{array}{c}\text { Romania (BSE } \\
\text { Composite) }\end{array}$ \\
\hline Bulgaria & & & & & & & & \\
\hline $\begin{array}{l}\text { Czech } \\
\text { Republic }\end{array}$ & 0.1796 & & & & & & & \\
\hline France & 0.1125 & 0.5253 & & & & & & \\
\hline Germany & 0.1143 & 0.4533 & 0.8773 & & & & & \\
\hline Hungary & 0.1182 & 0.5729 & 0.5208 & 0.4695 & & & & \\
\hline Poland & 0.0881 & 0.5811 & 0.5150 & 0.4743 & 0.5582 & & & \\
\hline $\begin{array}{l}\text { Romania } \\
\text { (BSE) }\end{array}$ & 0.1570 & 0.3877 & 0.2552 & 0.2280 & 0.3044 & 0.2731 & & \\
\hline $\begin{array}{l}\text { Romania (BSE } \\
\text { composite) }\end{array}$ & 0.1709 & 0.4062 & 0.2655 & 0.2419 & 0.3125 & 0.2807 & 0.9072 & \\
\hline Slovakia & 0.0248 & 0.0143 & 0.0068 & 0.0104 & 0.0067 & 0.0083 & 0.0211 & 0.0134 \\
\hline
\end{tabular}

In order to determine whether correlation patterns are stable over time, we divide our full sample into two sub-sample periods: a) pre-May 2005 and b) post-May 2005 based on the midpoint of the sample period. To identify the date of this division, we use standard Chow (1960) breakpoint tests of structural stability, which are discussed below. We then estimate correlation coefficients separately for each sub-sample period and the results are displayed in Tables $2 \mathrm{~b}$ and $2 \mathrm{c}$.

As shown, the correlation coefficients among stock returns generally increased in post-May 2005 subsample, compared to the pre-May 2005 sample. The only exception is the case of correlations between the Slovakian and French, German, and Polish stock market returns, which show a decline in the later sample period. This finding provides some evidence of stronger financial integration among these continental European stock markets over time and specifically following the expansion of the EU to include CEE countries. 
Table 2b | Correlation Matrix for National Stock Market Indexes, First Half of the Sample Period $(1 / 10 / 2000$ to $5 / 20 / 2005)$

\begin{tabular}{|l|l|l|l|l|l|l|l|l|}
\hline & Bulgaria & $\begin{array}{c}\text { Czech } \\
\text { Republic }\end{array}$ & France & Germany & Hungary & Poland & $\begin{array}{c}\text { Romania } \\
\text { (BSE) }\end{array}$ & $\begin{array}{c}\text { Romania (BSE } \\
\text { composite) }\end{array}$ \\
\hline Bulgaria & & & & & & & & \\
\hline $\begin{array}{l}\text { Czech } \\
\text { Republic }\end{array}$ & 0.0309 & & & & & & & \\
\hline France & 0.0341 & 0.3838 & & & & & & \\
\hline Germany & 0.0501 & 0.3288 & 0.8452 & & & & & \\
\hline Hungary & 0.0374 & 0.4569 & 0.4108 & 0.3782 & & & & \\
\hline Poland & -0.0303 & 0.4506 & 0.3965 & 0.3546 & 0.4586 & & & \\
\hline $\begin{array}{l}\text { Romania } \\
\text { (BSE) }\end{array}$ & -0.0142 & 0.0841 & 0.0174 & 0.0178 & 0.0640 & 0.0462 & & \\
\hline $\begin{array}{l}\text { Romania (BSE } \\
\text { Composite) }\end{array}$ & -0.0177 & 0.0889 & 0.0329 & 0.0419 & 0.0628 & 0.0557 & 0.7888 & \\
\hline Slovakia & -0.0038 & -0.0014 & 0.0244 & 0.0300 & -0.0017 & 0.0326 & -0.0264 & -0.0377 \\
\hline
\end{tabular}

Table 2c | Correlation Matrix for National Stock Market Indexes, Second Half of the Sample Period $(5 / 21 / 2005$ to $9 / 30 / 2010)$

\begin{tabular}{|l|l|l|l|l|l|l|l|l|}
\hline & Bulgaria & $\begin{array}{c}\text { Czech } \\
\text { Republic }\end{array}$ & France & Germany & Hungary & Poland & $\begin{array}{c}\text { Romania } \\
\text { (BSE) }\end{array}$ & $\begin{array}{c}\text { Romania(BSE } \\
\text { Composite) }\end{array}$ \\
\hline Bulgaria & & & & & & & & \\
\hline $\begin{array}{l}\text { Czech } \\
\text { Republic }\end{array}$ & 0.3346 & & & & & & & \\
\hline France & 0.2194 & 0.6354 & & & & & & \\
\hline Germany & 0.2175 & 0.5826 & 0.9211 & & & & & \\
\hline Hungary & 0.2056 & 0.6304 & 0.6089 & 0.5720 & & & & \\
\hline Poland & 0.2334 & 0.6688 & 0.6196 & 0.6075 & 0.6264 & & & \\
\hline $\begin{array}{l}\text { Romania } \\
\text { (BSE) }\end{array}$ & 0.3412 & 0.5538 & 0.4413 & 0.4301 & 0.4374 & 0.4319 & & \\
\hline $\begin{array}{l}\text { Romania (BSE } \\
\text { composite) }\end{array}$ & 0.3704 & 0.5756 & 0.4445 & 0.4324 & 0.4476 & 0.4354 & 0.9772 & \\
\hline Slovakia & 0.0568 & 0.0250 & -0.0114 & -0.0123 & 0.0130 & -0.0143 & 0.0571 & 0.0509 \\
\hline
\end{tabular}




\subsection{Methodology}

In order to examine the interdependency, the nature of the transmission of information, and the integration among the stocks markets being studied, we follow a procedure used by Ajayi, Mehdian and Perry (2010). This procedure involves three different econometric models. First, we estimate model (1) using the maximum likelihood approach:

Where:

$$
R_{i t}=C_{0}+\sum_{j=1}^{3} a_{i} R_{k(t+j)}+\sum_{j=0}^{3} b_{i} R_{k(t-j)}+\varepsilon_{i t}
$$

$R_{i t}=$ the daily returns on each CEE stock market $i$ on day $t$;

$C_{0}=$ the constant term;

$a_{i}$ and $b_{i}=$ lead and lag coefficients from one to three days correspondingly;

$R_{k}=$ the daily returns on the German or the French stock market;

$j=$ the number of leads or lags, from one to three days; and

$\varepsilon_{i t}=$ a random error term.

The coefficients $a_{i}$ measure the reaction of CEE stock markets to ex-ante price shocks in the stock markets of Germany and France, while the coefficients $b_{i}$ measure responses of the CEE stock markets to concurrent and ex-post price shocks from the German and French stock markets.

To test for the stability of the response patterns of CEE stock returns over time, we perform standard Chow breakpoint tests of structural stability of Equation (1). Specifically, we partition the data set at the mid-point of the full sample, forming two subsamples (Subsample 1 and Subsample 2): one for the first half of the sample from January 10, 2000 to May 20, 2005, and another for the second half of the sample from May 21, 2005 to September 30, 2010 (except for Bulgaria, which is October 23, 2000 to October $10,2005)$. We then estimate Equation (1) for each subsample separately and compare the coefficients $\left(a_{i 1}\right.$ to $a_{i 2}$, and $b_{i 1}$ to $b_{i 2}$ ) in each period to check for the structural stability of the model over time. The null hypothesis of the equality of the coefficients over both subsamples ( 1 and 2$)$ is as follows:

$$
H_{o}: a_{i 1}=a_{i 2} \text { and } b_{i 1}=b_{i 2} \text {. }
$$

The alternative hypothesis is that the coefficients are significantly different in the two subsample periods. A standard F-test is used to test for inter-temporal structural stability of the estimated coefficients over both subsamples.

In order to identify which Western continental European stock market, Germany or France, has more influence over the CEE stock markets, we modify Equation (1), to include daily stock returns from Germany and France as additional independent variables:

$$
R_{\mathrm{it}}=C_{0}+\sum_{j=1}^{3} a_{i} R_{G(t+j)}+\sum_{j=0}^{3} c_{i} R_{G(t-j)}+\sum_{j=1}^{3} b_{i} R_{F(t+j)}+\sum_{j=0}^{3} d_{i} R_{F(t-j)}+\varepsilon_{i t}
$$

Where:

$R_{i t}=$ the daily return of each CEE market $i$ on day $t$;

$a, c, b$ and $d=$ coefficients to be estimated; 
$R_{G}$ and $R_{F}=$ the daily returns of the German DAX and French CAC stock market indexes on day $t$, respectively;

$j=$ the number of leads or lags, from one to three days; and

$\varepsilon_{i t}=$ a random error term.

The values of the estimated coefficients of Equation (2) determine and measure which stock market, Germany or France, if either, has a greater influence on the daily returns for the CEE stock markets. The estimation will empirically test the null hypothesis below, that the sum of the estimated coefficients for Germany ( $a$ and $c$ ) is equal to the sum of those for France ( $b$ and $d$ ). If the null hypothesis below is rejected, it would suggest that the influences of Germany and France on the CEE markets are not equal.

$$
H_{0}: \sum_{j=1}^{3} a_{i}+\sum_{j=0}^{3} c_{i}=\sum_{j=1}^{3} b_{i}+\sum_{j=0}^{3} d_{i}
$$

In order to determine whether there is a transmission of volatility from the German and/ or French stock markets to the CEE equity markets, we use the following $\operatorname{GARCH}(1,1)$ model:

$$
\begin{gathered}
R_{i t}=\gamma_{0}+\sum_{i=1}^{n} \gamma_{i} L_{i} R_{i t}+\varepsilon_{t} \\
\varepsilon_{t} \mid \Phi_{t-1} \sim N\left(0, h_{t}\right) \\
h_{t}=\alpha_{0}+\alpha_{1} \varepsilon_{t-1}^{2}+\beta_{1} h_{t-1}+\delta_{G} R_{G} \\
h_{t}=\alpha_{0}+\alpha_{1} \varepsilon_{t-1}^{2}+\beta_{1} h_{t-1}+\delta_{F} R_{F}
\end{gathered}
$$

Where:

$R_{i t}=$ the daily return of market $i$ of CEE area on day $t$;

$L=$ the lag operator;

$h_{t}=$ the conditional variance corresponding to CEE stock market returns;

$R_{\mathrm{G}}$ and $R_{\mathrm{F}}=$ the stock market returns of Germany and France, respectively;

$\gamma, \alpha, \beta, \delta=$ vectors of parameters to be estimated; and

$\varepsilon_{t}=$ a random error term.

The requirements for the conditional variance to be stable are $\alpha_{0}>0, \alpha_{1}^{3} 0, \beta_{1}{ }^{3} 0$, and $\alpha_{1}+\beta_{1}<1$. We added daily returns of Germany and France in the models in order to incorporate the associated volatility leakages. The sum of the estimated coefficients $\left(\alpha_{1}+\beta_{1}\right)$ measures the persistence of volatility reaction to the price innovations. The closer the value of $\left(\alpha_{1}+\beta_{1}\right)$ is to a value of 1 , the more persistent are the volatility shocks.

On the other hand, if $\delta_{G}>0$, then the results would indicate the presence of price innovations from Germany. If $\delta_{F}>0$, the results would imply spillover effects from France. In general, if the estimated coefficients $\delta_{G}$ and $\delta_{F}$ are both positive, then the persistence level of volatility $\left(\alpha_{1}+\beta_{1}\right)$ should decline as the GARCH effects capture the second moment impact of the external shocks.

Finally, to examine the dynamics of interdependency of the daily returns between: a) Germany and France, and b) the CEE countries, we use a Vector Autoregressive model (VAR) with the following form: 
Where:

$$
R_{t}=\alpha_{1}+\sum_{k=1}^{K} \beta_{k} R_{t-k}+\sum_{k=1}^{K} \beta_{k} R_{G, t-k}+\sum_{k=1}^{K} \beta_{k} R_{F, t-k}+\varepsilon_{t}
$$

$R_{t}=$ the daily return of each country under study on day $\mathrm{t}$; and

$R_{G}$ and $R_{F}=$ daily returns on German and French stock indexes, respectively, treated as endogenous variables.

As can be seen in Equation (7), the return of a CEE national stock index is not only a function of its own lagged returns, but also a function of lagged returns from the German and French stock markets.

One advantage of VAR models is that they provide an opportunity to investigate the reaction of each CEE stock market to its own price shocks and the price innovations from Germany and France as well. Empirically, the variance decomposition series assesses the interdependency between the markets to the extent that one market reacts to the price shocks and innovations from other markets. In this paper, we focus on the interdependency between each of the CEE markets and Germany and France, and the influences and effects of price innovations of these two countries of the Continental Europe on CEE equity markets.

\section{Empirical Results}

Table 3 displays the estimated coefficients of Equation (1) for each of the CEE countries using a maximum likelihood approach over the entire sample from January 10, 2000 to September 30, 2010 (except for Bulgaria, which is October 23, 2000 to September 30, 2010).

While the results generally indicate no major pattern of CEE responses to price shocks from Germany and France, we observe some statistically significant contemporaneous and lagged reactions from the CEE markets to price innovations and external shocks from Germany and France, with the exception of the Slovakian stock market. In the case of the Slovakian market, only one coefficient is significant (besides the intercept), which is the lead influence from daily returns in Germany. This finding for Slovakia is consistent with earlier results of the correlation analysis, in which we detected very little correlation between the Slovakian market and the other markets under study. Additionally, Bulgaria, Hungary, Poland, Romania and Slovakia show statistically significant reaction to lead price innovations from Germany in three cases and France in one case. On the other hand, we detect statistically significant response to lagged innovations from stock markets in Germany and France in the case of stock markets in the Czech Republic, Hungary, and Poland.

To examine the reactions of CEE stock markets to shocks from the stock markets of Germany and France further, we partition our sample into two subsamples. The first half of the sample runs from January 10, 2000 to May 20, 2005, and the second half is from May 21, 2005 to September 30, 2010 (except for Bulgaria where the break point is October 10, 2005). We then re-estimate Equation (2) for each country, and the results are displayed in Tables $3 \mathrm{a}$ and $3 \mathrm{~b}$. As the figures of Table $3 \mathrm{a}$ suggest, in the first period, only the stock markets of the Czech Republic, Hungary and Poland demonstrate statistically significant responses to contemporaneous and lagged innovations from the stock markets of Germany and France. However, the exception is the Bucharest SE composite index, 
which shows a reaction to lagged innovations and Hungary, and exhibits responsiveness to lead innovations from Germany's stock market. Again, no responsiveness is observed from the Slovakian stock market to innovations from either the German or the French stock market in the first period.

Table 3 | National Response Patterns: Maximum - Likelihood Estimates of Equation 1

\begin{tabular}{|c|c|c|c|c|c|c|c|c|c|c|c|}
\hline & & \multicolumn{4}{|c|}{ Coefficients of Leads } & \multicolumn{4}{|c|}{ Coefficients of Lags } & \multirow{2}{*}{ D-W } & \multirow{2}{*}{$\mathbf{R}^{2}$} \\
\hline & & $c_{0}$ & $a_{3}$ & $a_{2}$ & $a_{1}$ & $b_{0}$ & $b_{1}$ & $b_{2}$ & $b_{3}$ & & \\
\hline \multirow{2}{*}{ Bulgaria } & France & .065 & .028 & .036 & -.036 & .139 & .092 & .007 & .002 & 2.00 & .022 \\
\hline & Germany & .066 & .014 & .011 & -.038 & .131 & .096 & .006 & -.012 & 2.00 & .023 \\
\hline \multirow{2}{*}{$\begin{array}{l}\text { Czech } \\
\text { Republic }\end{array}$} & France & .034 & .009 & -.014 & -.009 & .529 & .127 & .023 & -.002 & 1.95 & .029 \\
\hline & Germany & .041 & .017 & -.009 & -.019 & .438 & .149 & .026 & -.009 & 1.97 & .231 \\
\hline \multirow{2}{*}{ Hungary } & France & .040 & -.003 & -.005 & .004 & .559 & .092 & -.008 & .053 & 1.94 & .281 \\
\hline & Germany & .047 & -.013 & .020 & -.017 & .482 & .143 & -.010 & .027 & 1.97 & .241 \\
\hline \multirow{2}{*}{ Poland } & France & .016 & .029 & .023 & .018 & .560 & .064 & .014 & .045 & 2.00 & .021 \\
\hline & Germany & .024 & .016 & .010 & .017 & .492 & .099 & .003 & .030 & 2.04 & .023 \\
\hline \multirow{2}{*}{$\begin{array}{l}\text { Romania } \\
\text { (BSE) }\end{array}$} & France & .094 & -.032 & -.021 & -.002 & .298 & .133 & .002 & .024 & 1.82 & .079 \\
\hline & Germany & .098 & -.031 & -.021 & -.010 & .124 & .126 & -.004 & .009 & 1.82 & .066 \\
\hline \multirow{2}{*}{$\begin{array}{l}\text { Romania } \\
\text { (BSE comp.) }\end{array}$} & France & .082 & -.029 & -.013 & .001 & .283 & .134 & -.007 & .031 & 1.70 & .088 \\
\hline & Germany & .085 & -.032 & -.016 & -.007 & .246 & .131 & -.011 & .012 & 1.70 & .076 \\
\hline \multirow{2}{*}{ Slovakia } & France & .044 & .001 & -.001 & -.005 & .007 & .019 & .016 & -.003 & 1.99 & .001 \\
\hline & Germany & .044 & .028 & .001 & -.005 & .008 & .007 & .005 & -.016 & 1.99 & .002 \\
\hline
\end{tabular}

Sample period is 1/10/2000 to 9/30/2010, except for Bulgaria, which starts on 10/23/2000.

Coefficients in bold are statistically significant at the 1,5 or $10 \%$ level. 
Table 3a | National Response Patterns: Maximum - Likelihood Estimates of Equation 1

\begin{tabular}{|c|c|c|c|c|c|c|c|c|c|c|c|}
\hline & & \multicolumn{4}{|c|}{ Coefficients of Leads } & \multicolumn{4}{|c|}{ Coefficients of Lags } & \multirow{2}{*}{ D-W } & \multirow{2}{*}{$\mathbf{R}^{2}$} \\
\hline & & $c_{0}$ & $a_{3}$ & $a_{2}$ & $a_{1}$ & $\boldsymbol{b}_{0}$ & $b_{1}$ & $b_{2}$ & $b_{3}$ & & \\
\hline \multirow{2}{*}{ Bulgaria } & France & .189 & -.005 & .008 & -.053 & .042 & -.061 & .007 & -.010 & 2.16 & .004 \\
\hline & Germany & .187 & -.043 & -.009 & -.032 & .051 & -.031 & .001 & -.027 & 2.16 & .005 \\
\hline \multirow{2}{*}{$\begin{array}{l}\text { Czech } \\
\text { Republic }\end{array}$} & France & .066 & -.006 & .017 & .009 & .315 & .029 & .013 & .037 & 1.96 & .146 \\
\hline & Germany & .076 & -.001 & .029 & .013 & .240 & .063 & .006 & .023 & 2.00 & .118 \\
\hline \multirow{2}{*}{ Hungary } & France & .053 & -.011 & .018 & -.024 & .360 & .023 & .024 & .047 & 1.96 & .165 \\
\hline & Germany & .064 & -.015 & .034 & -.013 & .294 & .078 & .002 & .044 & 2.01 & .158 \\
\hline \multirow{2}{*}{ Poland } & France & .009 & .013 & .025 & .024 & .408 & .033 & .032 & .088 & 2.00 & .021 \\
\hline & Germany & .023 & .015 & .018 & .022 & .322 & .079 & .006 & .056 & 2.03 & .135 \\
\hline \multirow{2}{*}{$\begin{array}{l}\text { Romania } \\
\text { (BSE) }\end{array}$} & France & .175 & -.019 & -.001 & -.022 & .012 & .026 & -.022 & -.026 & 1.62 & .003 \\
\hline & Germany & .174 & -.012 & .008 & -.012 & .014 & .019 & -.021 & -.016 & 1.63 & .002 \\
\hline \multirow{2}{*}{$\begin{array}{l}\text { Romania } \\
\text { (BSE Comp.) }\end{array}$} & France & .161 & -.020 & .004 & -.017 & .026 & .013 & -.039 & -.002 & 1.36 & .003 \\
\hline & Germany & .160 & -.020 & .006 & -.006 & .032 & .017 & -.037 & -.005 & 1.36 & .005 \\
\hline \multirow{2}{*}{ Slovakia } & France & .131 & -.001 & -.020 & .013 & .019 & .035 & .007 & -.001 & 1.97 & .003 \\
\hline & Germany & .132 & .025 & -.012 & .005 & .022 & .015 & -.001 & -.031 & 1.97 & .005 \\
\hline
\end{tabular}

Sample period is 1/10/2000 to 5/20/2005, except for Bulgaria, which is $10 / 23 / 2000$ to $10 / 10 / 2005$.

Coefficients in bold are statistically significant at the $1 \%, 5 \%$ or $10 \%$ level.

According to the results displayed in Table $3 \mathrm{~b}$, during the second period, from mid-2005 to September 2010, all CEE stock markets in the sample, except for Slovakia, demonstrate statistically significant responsiveness to the contemporaneous, lead and lagged innovations from daily stock price innovations in Germany and France. We note that these countries respond equally to price innovations from Germany and France, while they react more to the contemporaneous and lagged price shocks in these countries. It is interesting to note that the Romanian stock market during the first period displays no significant reaction to any price innovations from the stock markets of Germany or France (only lagged coefficients are significant), while in the second period it displays significant responsiveness to contemporaneous, lead and lagged market developments from both markets. 
Table 3b | National Response Patterns: Maximum - Likelihood Estimates of Equation 1

\begin{tabular}{|c|c|c|c|c|c|c|c|c|c|c|c|}
\hline & & \multicolumn{4}{|c|}{ Coefficients of Leads } & \multicolumn{4}{|c|}{ Coefficients of Lags } & \multirow{2}{*}{ D-W } & \multirow{2}{*}{$\mathbf{R}^{2}$} \\
\hline & & $c_{0}$ & $a_{3}$ & $a_{2}$ & $a_{1}$ & $b_{0}$ & $b_{1}$ & $b_{2}$ & $b_{3}$ & & \\
\hline \multirow{2}{*}{ Bulgaria } & France & -.063 & .051 & .065 & -.008 & .238 & .235 & .027 & .016 & 1.79 & .124 \\
\hline & Germany & -.066 & .084 & .046 & -.032 & .237 & .262 & .014 & .012 & 1.78 & .138 \\
\hline \multirow{2}{*}{$\begin{array}{l}\text { Czech } \\
\text { Republic }\end{array}$} & France & -.002 & .017 & -.037 & -.008 & .745 & .238 & .048 & -.036 & 2.03 & .452 \\
\hline & Germany & -.007 & .045 & -.046 & -.054 & .710 & .261 & .069 & -.045 & 2.03 & .399 \\
\hline \multirow{2}{*}{ Hungary } & France & .022 & -.002 & -.016 & .048 & .758 & .174 & -.025 & .058 & 1.99 & .395 \\
\hline & Germany & .017 & -.008 & .018 & -.016 & .739 & .231 & -.015 & .011 & 1.91 & .360 \\
\hline \multirow{2}{*}{ Poland } & France & .020 & .045 & .029 & .028 & .710 & .102 & .001 & .003 & 2.01 & .394 \\
\hline & Germany & .015 & .022 & .012 & .012 & .723 & .125 & .010 & .001 & 2.07 & .381 \\
\hline \multirow{2}{*}{$\begin{array}{l}\text { Romania } \\
\text { (BSE) }\end{array}$} & France & .003 & -.056 & -.034 & .036 & .589 & .266 & .052 & .080 & 1.82 & .079 \\
\hline & Germany & .001 & -.059 & -.043 & -.001 & .586 & .278 & .040 & .059 & 2.08 & .231 \\
\hline \multirow{2}{*}{$\begin{array}{l}\text { Romania } \\
\text { (BSE } \\
\text { Comp.) }\end{array}$} & France & -.006 & -.048 & -.022 & .039 & .547 & .278 & .048 & .072 & 2.08 & .257 \\
\hline & Germany & -.010 & -.053 & -.032 & -.001 & .542 & .290 & .042 & .052 & 2.06 & .245 \\
\hline \multirow{2}{*}{ Slovakia } & France & .044 & .001 & -.001 & -.005 & .007 & .019 & .016 & -.003 & 1.99 & .001 \\
\hline & Germany & -.042 & .030 & .019 & -.018 & -.007 & -.001 & .012 & .006 & 2.04 & .003 \\
\hline
\end{tabular}

Sample period is 5/21/2005 to 9/30/2010, except for Bulgaria which is 10/11/2005 to 9/30/2010.

Coefficients in bold are statistically significant at the $1 \%, 5 \%$ or $10 \%$ level.

In sum, the differences in the results in Table $3 \mathrm{a}$ and Table $3 \mathrm{~b}$ indicate significant integration and increasing dependency among the stock markets of the Eastern and Western continental European countries, except for the Slovakian stock market.

In order to test whether the estimated coefficients given in Table 3 are structurally stable over time, we performed Chow breakpoint tests, as explained in the Methodology section. Table 4 displays the sample midpoint that is used as the breakpoint, and the results of the Chow tests. As can be seen, we rejected the $\mathrm{H}_{\mathrm{o}}$ of structural stability over time and the hypotheses that the slopes, intercepts, and the overall regressions are the same over the entire sample, in favour of the alternative hypothesis that they are significantly different in the two periods. These findings validate our decision to break the full sample into two sub-periods and re-estimate Equation (2) as we did, with the empirical results presented in Tables $3 a$ and $3 b$. 
Table 4 | Test of Inter-Temporal Stability

\begin{tabular}{|l|c|c|c|}
\hline \multirow{2}{*}{} & \multirow{2}{*}{ Midpoint of Sample } & \multicolumn{2}{|c|}{ F-Statistics } \\
\cline { 3 - 4 } & & France & Germany \\
\hline Bulgaria & $10 / 10 / 2005$ & $11.27^{* * *}$ & $9.50^{* * *}$ \\
\hline Czech Republic & $5 / 20 / 2005$ & $32.06^{* * *}$ & $37.69^{* * *}$ \\
\hline Hungary & $5 / 20 / 2005$ & $21.00^{* * *}$ & $25.54^{* * *}$ \\
\hline Poland & $5 / 20 / 2005$ & $11.40^{* * *}$ & $18.54^{* * *}$ \\
\hline Romania (BSE) & $5 / 20 / 2005$ & $30.55^{* * *}$ & $32.81^{* * *}$ \\
\hline Romania (BSE Comp.) & $5 / 20 / 2005$ & $32.42^{* * *}$ & $33.98^{* * *}$ \\
\hline Slovakia & $5 / 20 / 2005$ & $2.49^{* *}$ & $2.40^{* *}$ \\
\hline
\end{tabular}

The test of the null hypothesis that the slopes, intercepts, and the overall regressions are the same intertemporally over the entire sample against the alternative hypothesis that they are different.

*** Significant at the $1 \%$ level and ** Significant at 5\% level.

Table 5 presents the results of the relative influence of daily stock market returns in Germany and France on the daily returns in the stock markets of the CEE countries. Figures in this table indicate whether the stock markets in France and Germany have equal impact on the stock market returns in the CEE countries.

Table 5 | Test of the Relative Influence of Germany and France on Central and Eastern European Stock Markets

\begin{tabular}{|l|c|}
\hline & Germany vs. France (F-statistic) \\
\hline Bulgaria & 0.120 \\
\hline Czech Republic & 0.316 \\
\hline Hungary & 0.735 \\
\hline Poland & 0.120 \\
\hline Romania (BSE) & $3.88^{* *}$ \\
\hline Romania (BSE Comp.) & $4.59^{* *}$ \\
\hline Slovakia & 0.652 \\
\hline
\end{tabular}

F-statistics are for the null hypothesis that cumulative lead and lag coefficients are the same for Germany and France (Equation 2).

** indicates significance at the $5 \%$ level.

Based on the results in Table 5, we cannot reject the null hypothesis that the cumulative lead and lag coefficients are the same for Germany and France, except in the case of both Romanian stock market indexes. This suggests that there are statistically significant differences between the relative impact of Germany and France on Romanian equity markets, while these differences are not significant for the other countries. 
Table 6 provides the maximum likelihood estimates of GARCH $(1,1)$ models where price innovations from German and French market are assumed to affect the volatility of returns in the CEE stock markets. The results in this table include estimates of the GARCH coefficients $\left(\alpha_{1}\right.$ and $\left.\beta_{1}\right)$ and spillover coefficients for the stock market returns in Germany and France $\left(\delta_{G}\right.$ and $\left.\delta_{F}\right)$. In the light of the results in Table 6 , the volatility spillover coefficients are in general smaller than the GARCH coefficients $\alpha_{1}$, and $\beta_{1}$, but they are statistically significant for all countries, except for Romania. The volatility spillover effects from France are slightly greater than those from Germany. In addition, the GARCH coefficients are statistically significant and their sums in all cases, except in the case of Bulgaria, are extremely close to one, suggesting that volatility shocks are persistent. This leads us to believe in general that the German and French equity markets affect the conditional variance of daily returns in the CEE equity markets, and that there are significant volatility spillover effects from stock market returns in Germany and France into the stock markets of the CEE countries.

Table 6 | Maximum Likelihood Estimates of GARCH Models with Innovations from the Germany and France

\begin{tabular}{|c|c|c|c|c|c|}
\hline Country & $a_{1}$ & $\beta_{1}$ & $\delta_{\mathrm{FR}}$ & $\delta_{\mathrm{GE}}$ & $a_{1}+\beta_{1}$ \\
\hline \multirow{3}{*}{ Bulgaria } & $.129 * * *$ & $.851^{* * *}$ & & & .980 \\
\hline & $.214^{* * *}$ & $.634^{* * *}$ & $-.180^{* * *}$ & & .848 \\
\hline & $.119 * * *$ & $.859^{* * *}$ & & $-.053^{* * *}$ & .978 \\
\hline \multirow{3}{*}{ Czech Republic } & $.122^{* * *}$ & $.858^{* * *}$ & & & .980 \\
\hline & $.111^{* * * *}$ & .861 & $-.070^{* * *}$ & & .972 \\
\hline & $.114^{* * *}$ & $.857^{* * *}$ & & $-.051^{* * *}$ & .971 \\
\hline \multirow{3}{*}{ Hungary } & $.089 * * *$ & $.889 * * *$ & & & .978 \\
\hline & $.075^{* * *}$ & $.903^{* * *}$ & $-.069^{* * *}$ & & .978 \\
\hline & $.076^{* * *}$ & $.900 * * *$ & & $-0.056^{* * *}$ & .976 \\
\hline \multirow{3}{*}{ Poland } & $.052^{* * *}$ & $.938^{* * *}$ & & & .990 \\
\hline & $.041^{* * *}$ & $.946^{* * *}$ & $-.069 * * *$ & & .987 \\
\hline & $.046^{* * *}$ & $.941^{* * * *}$ & & $-.051^{* * *}$ & .987 \\
\hline \multirow{3}{*}{ Romania (BSE) } & $.167^{* * *}$ & $.789 * * *$ & & & .956 \\
\hline & $.166^{* * *}$ & $.789 * * *$ & -.004 & & .955 \\
\hline & $.164^{* * *}$ & $.790 * * *$ & & -.014 & .954 \\
\hline \multirow{3}{*}{$\begin{array}{l}\text { Romania (BSE } \\
\text { Comp.) }\end{array}$} & $.239^{* * *}$ & $.706^{* * *}$ & & & .954 \\
\hline & $.236^{* * *}$ & $.706^{* * *}$ & $-.019^{*}$ & & .945 \\
\hline & $.228^{* * *}$ & $.712^{* * *}$ & & $-.037^{* * *}$ & .940 \\
\hline \multirow{3}{*}{ Slovakia } & $.034^{* * *}$ & $.962^{* * *}$ & & & .996 \\
\hline & $.033^{* * *}$ & $.963^{* * *}$ & $.002^{* * *}$ & & .996 \\
\hline & $.034^{* * *}$ & $.962^{* * *}$ & & $.004^{* *}$ & .996 \\
\hline
\end{tabular}

***Significant at the $1 \%$ level, ${ }^{* *}$ Significant at the $5 \%$ level, ${ }^{*}$ Significant at the $10 \%$ level. 
Table 7 contains the decomposition of forecast error variances of daily market returns in the CEE markets for 3, 5, and 10-day ahead forecasts. We performed this decomposition analysis by estimating the VAR model of Equation (7).

Table 7 | Forecast Error Variance Decomposition of Daily Market Returns in the Central and Eastern European Markets

\begin{tabular}{|c|c|c|c|c|}
\hline Country & Days Ahead & Own Innovation & France Innovation & Germany Innovation \\
\hline \multirow{3}{*}{ Bulgaria } & 3 & 99.25 & .607 & .137 \\
\hline & 5 & 99.25 & .612 & .137 \\
\hline & 10 & 99.25 & .613 & .137 \\
\hline \multirow{3}{*}{$\begin{array}{l}\text { Czech } \\
\text { Republic }\end{array}$} & 3 & 98.05 & .570 & 1.37 \\
\hline & 5 & 97.96 & .594 & 1.43 \\
\hline & 10 & 97.96 & .596 & 1.44 \\
\hline \multirow{3}{*}{ Hungary } & 3 & 97.98 & .112 & 2.10 \\
\hline & 5 & 97.68 & .201 & 2.11 \\
\hline & 10 & 97.68 & .204 & 2.11 \\
\hline \multirow{3}{*}{ Poland } & 3 & 98.81 & .057 & 1.13 \\
\hline & 5 & 98.75 & .064 & 1.17 \\
\hline & 10 & 98.75 & .065 & 1.17 \\
\hline \multirow{3}{*}{$\begin{array}{l}\text { Romania } \\
\text { (BSE) }\end{array}$} & 3 & 99.31 & .612 & .069 \\
\hline & 5 & 99.29 & .631 & .069 \\
\hline & 10 & 99.29 & .633 & .069 \\
\hline \multirow{3}{*}{$\begin{array}{l}\text { Romania } \\
\text { (BSE Comp.) }\end{array}$} & 3 & 99.20 & .685 & .109 \\
\hline & 5 & 99.18 & .694 & .118 \\
\hline & 10 & 99.18 & .695 & .118 \\
\hline \multirow{3}{*}{ Slovakia } & 3 & 99.11 & .767 & .115 \\
\hline & 5 & 99.08 & .773 & .141 \\
\hline & 10 & 99.08 & .774 & .141 \\
\hline
\end{tabular}

The last three columns of Table 7 display the percentages explained of the total forecast error for each country included in the sample. The first column of the last three columns shows the proportion of the forecast error accounted for by a country's own national stock market innovations, the next column shows the proportion of the forecast error accounted for by French stock market innovations, and the last column displays the share of the forecast error accounted for by German market innovations. The results in Table 6 imply that in all counties investigated, the national market price innovations 
account for more of the error variance, while France and German price innovations account for less of the forecast error variance. However, a closer examination of the findings reported in Table 7 reveals that the relative influence of France is greater than Germany's, because French price innovations account for more of the error variance of the CEE countries than German price innovations.

\section{Summary and Conclusions}

We examined the transmission of financial information across the stock markets of the Czech Republic, Hungary, Poland, Slovakia (which have all joined the European Union since 2004), and Bulgaria and Romania (EU members since 2007), in order to empirically investigate the degree of integration of these equity markets. We took into consideration the recent transformations in the European stock markets, including the increasing market trend towards more partnerships and acquisitions, and for expanding the regional influence in the CEE area.

To investigate the transmission of financial information from the stock markets of Germany and France to the CEE stock markets, the effects of external price innovations and shocks across the equity markets under study, and the interdependency of the national stock markets, we employed three econometric models. These models were estimated using maximum likelihood regression, GARCH, and vector autoregression (VAR). In addition, we examined the relative importance and influence of the advanced equity markets of continental Europe (Germany and France) on CEE equity markets.

Our findings confirm that the CEE stock markets react to the arrival of price innovations from the equity markets of Germany and France. However, the pattern and nature of these reactions and responses are mixed across CEE markets. In addition, Slovakia was the only country in general that has maintained its independence from the influence of the stock markets of Germany and France, and has not experienced a significant degree of integration. We speculate that the independence of Slovakia is due to its relatively low market capitalization compared to the other equity markets in the region, and the possible lack of interest from foreign investors to trade in this market. In addition, we found that intra-national market price innovations account for more of the error variance than external innovations from either Germany or France. 


\section{References}

Ajayi, R., Mehdian, S., Perry, M. (2010), "The Relative Influence of the East and the West on Middle Eastern Emerging Markets: An Empirical Investigation." Applied Financial Economics, Vol. 20, No. 5, pp. 407-415.

Bailey, W., Stulz, R. (1990), "Benefits of International Diversification: The Case of Pacific Basin Stock Markets." Journal of Portfolio Management, Vol. 16, No. 4, pp. 57-61.

Baltzer, M., Cappiello, L., De Santis, R. A., Manganelli, S. (2008), “Measuring Financial Integration in New EU Member States." European Central Bank, Occasional Paper Series, No. 81, pp. 1-36.

Bora, A., Mandaci, P. E., Kopurlu, B. S., Ersener, B. (2009), “Behaviour of Emerging Stock Markets in the Global Financial Meltdown: Evidence from BRICA." African Journal of Business Management, Vol. 3, No. 7, pp. 396-404.

Cheung, Y. L., Ho, Y. K. (1991), "The Intertemporal Stability of the Relationship between the Asian Emerging Equity Markets and the Developed Equity Markets." Journal of Business Finance and Accounting, Vol. 18, No. 2, pp. 235-254.

Chow, G. C. (1960), "Tests of Equality between Sets of Coefficients in Two Linear Regressions." Econometrica, Vol. 28, No. 3, pp. 591-605.

Dickinson, G. (2000), "The Implications of Lower Interest Rates for Insurers: A Comment." Geneva Papers on Risk and Insurance, Vol. 25, No. 1, pp. 59-62.

Dimpfl, T., Jung, R. (2011), "Financial Market Spillovers around the Globe." Working Papers on Global Financial Markets, No. 20, University Jena, pp. 1-28.

Erkan, H. (2008), "How Can We Increase the Attractiveness of the Region as an Area for Investment?" Conference on the Prospects for Capital Markets in Southeast Europe, Sofia.

Forbes, K. J., Rigobon, R. (2002), “No Contagion, Only Interdependence: Measuring Stock Market Co-movements." Journal of Finance, Vol. 57, No. 5, pp. 2223-2261.

Harrison, B., Moore, W. (2009), "Spillover Effects from London and Frankfurt to Central and Eastern European Stock Markets." Applied Financial Economics, Vol. 19, No. 18, pp. 1509-1521.

Koch, P. D., Koch, T. W. (1991), “Evolution in Dynamic Linkages across Daily National Stock Indexes." Journal of International Money and Finance, Vol. 10, No. 2, pp. 231-51.

Longin, F., Solnik, B. (2001), "Extreme Correlation of International Equity Markets." Journal of Finance, Vol. 56, No. 2, pp. 649-676.

Ng, A. (2000), "Volatility Spillover Effects from Japan and the U.S. to the Pacific-Basin." Journal of International Money and Finance, Vol. 19, No. 2, pp. 207-233.

Peša, A. R., Festić, M. (2012), "Testing the "EU Announcement Effect” on Stock Market Indices and Macroeconomic Variables in Croatia between 2000 and 2010." Prague Economic Papers, Vol. 21, No. 4, pp. 450-469.

Shachmurove, Y. (2005), "Dynamic Linkages among the Emerging Middle Eastern and the United States Markets." International Journal of Business, Vol. 10, No. 1, pp. 103-132.

Wongswan, J. (2006), "Transmission of Information across International Equity Markets." Review of Financial Studies, Vol. 19, No. 4, pp. 1157-1189.

Yalama, A. (2009), "Stock Market Linkages in Emerging Markets: Evidence from Turkey and Brazil." Banks and Bank Systems, Vol. 4, No. 3, pp. 71-78. 